\title{
Parental Role In Molding The Character Of Their Children
}

\author{
Theophilus Oludare Aliu \\ Chaplaincy Department, Faculty of Humanities, Social and Management Sciences, \\ Bingham University, Karu, Nigeria
}

\begin{abstract}
The family remains an important unit in the society and in God's plan. Parents as heads of the family have been saddled with the responsibility of taking care of these young ones. The society has changed because parents have faced other issues rather than the primary duty of building their children. Apostle Paul however, focused on the duties of parents to their children in Ephesians 6:4. This article therefore focuses on Paul's prescriptions for parents in order to restore sanity to the society by building godly character in the children.
\end{abstract}

\section{INTRODUCTION}

The decadence plaguing the world is a matter of serious concern. It is a concern that deserves assessment in all spheres of life and every sector of society. Efforts to stem the tide are proving ineffective as the woes are expanding their frontiers. Money is being expended in millions to find solution that will cub the menace being perpetrated by miscreants in the society. But who are these miscreants? Are they not sons, daughters, brothers, sisters, wives, husbands, fathers or mothers to some people in the society? In other words, they are people that arose from homes with relatives in the vicinity. This paper intends to look in the direction of parents, reminding and arousing them to taking up their godly ordained responsibility. This is because parents have the first duty of nurturing a child in the way he/she should go.

The very first environment where a baby wakes up to consciousness is a home containing a father and a mother. ${ }^{1}$ These were the child's first gods. Paul in his epistle to the Ephesians exhorted parents not to exasperate their children; instead, they are to bring children up in the training and instruction of the Lord. These instructions which are the focal point of this article are informative about the duties prescribed for parents in the word of God. It is the abdication of these obligations that has caused the rootless evil in our society.

Before we examine the parental role as commanded in Scripture, we shall observe the make-up of our society to see some factors responsible for the ills.

\section{CHARACTERISTICS OF OUR MODERN SOCIETY}

Douglas Rhymes ${ }^{2}$ presented a list of traits being exhibited in the present day society. He wrote that the society is one: (1) with no explicit philosophy or sense of meaning; (2) with an existential outlook; (3) of much noise, many contacts and considerable mobility; (4) needing community and understanding of relationship.

\subsection{SOCIETY WITH NO EXPLICIT PHILOSOPHY OR SENSE OF MEANING}

The society in which we live now is one that resents official aims and purposes and has no explicit philosophy. It is a neutral and secular society where no one can govern by divine rules for no group has the right to impose its idea on another. The secularity is further complicated by its pragmatism and profanity. ${ }^{3}$

Pragmatism is concerned with what works instantly, what functions effectively and what is relevant. It is a generation that believes in now. They say things like 'get what you want now', 'delay is dangerous' and 'tomorrow is not yours.' Pragmatism as an idea was propounded by C. S. Peirce and William James. The forte

${ }^{1}$ Some children grow up in a different atmosphere. This could be under the custody of one of the parents, the grand parents or some other guardians. A substantial number of homes today are managed by one of the parents. No thanks to a society that view divorce with approval and without guilt.

${ }^{2}$ Douglas Rhymes, Prayer in the secular city, (Pennsylvania: Westminster Press, 1967), 12

${ }^{3}$ Douglas Rhymes, 12 
of their argument is that "the meaning of conceptions is to be sought in their practical bearings, that the function of thought is to guide action, and that truth is preeminently to be tested by the practical consequences of belief."

Profanity has to do with humanity's rejection of divinity. It refers to the disappearance of supramundane reality defining life. The world is not to be viewed in terms of some other world but in terms of itself. They disliked the idea of any divine intervention of a God to be effectual means of dealing with diseases and war. They taught that the answer to human pain lies in the "field of medical research, in the right use of nuclear and economic research; and the answer to man's sense of guilt lies in psychological analysis." ${ }^{\circ}$

\subsection{SOCIETY WITH AN EXISTENTIAL OUTLOOK}

Modern society is ruled by its philosophy of existentialism. The purpose of existence and the meaning of life are questions that many seek answer to. The younger generation is eager to find meaning of ultimate reality. So they enquire: What is ultimate reality? What is the nature of the world around us? What does it mean to be human? What happens when I die? On what basis are we able to know anything at all? How do we determine right or wrong? What is the meaning of history? Where did we come from and who are we? What has gone wrong with the world? What can we do to fix it? How shall we live? It is all question upon question as humankind seek to know the purpose for their existence.

The Bible is the only guide that answers these questions to man's satisfaction. The Bible narrates in clear terms the creation of humans, the dignifying traits, the commissioning and assignments but also the degrading of humans by sin. Human's rejection of the truth of God as regards creation gave way to the promulgation of spurious ideas about the purpose of human existence.

\subsection{SOCIETY OF MUCH NOISE, MANY CONTACTS AND CONSIDERABLE MOBILITY}

'Be still and know that I am God' tend to have over stayed its time. The society of young people believes in noise making. A visit to youth clubs, homes and gatherings of young people make you witness deafening noise that makes conversation impossible. Almost every youth of today carries along with him/her a phone, laptop or I-pad with earpiece attached. Some of them even claim to be studying with these distracters. This does not fit into the need for quietness which has always been the background for meditation, contemplation, concentration and meaningful study.

Additionally, modern society is also disturbed by pressure of time. There are too many activities to carry out but too little time to achieve considerable success. Officers often pile up assignments in offices and carry behind them unfinished jobs. With this comes pressure of living. Bills to settle: light bills, health bills, school fees, rents and other day to day obligations.

Movement from place to place is another characteristic of this age. People move from one place to another in search of jobs and comfort. Government officials are taken from one location to another. Families (wives, husbands and children) live at different locations separated by their jobs and schooling. This creates inconveniences most of the time, because when people move from one location to another they move intellectually, financially, psychologically and spiritually. When parents move, the children also go with them. This necessitates change of school, adjustment in finances, health challenges etc.

\subsection{SOCIETY NEEDING COMMUNITY AND UNDERSTANDING OF RELATIONSHIP}

Increase in mobility comes with some resultant effect. Movement from place to place creates loneliness, anonymity and privacy. The design of present day block of flats also contribute to loneliness. Do your thing, I do mine has increased with the passing day. This factor is supposed to aid oneness of family but it has created an individualistic living that has shielded children away from both the good and the bad influences in society.

All the factors enumerated above have affected parenting in no small measure. However, the word of God has its precepts recommended to parents as they take up the challenge of parenting which is a big role in molding the life of their children. We now turn to Ephesians 6:4 to discuss some precepts laid down for us and clearly enunciated as parental responsibilities which if adhered to can bring some sanity back to society.

\section{WHY THE FATHERS?}

The focus on the fathers 'pateres' here is predicated on the fact that fathers are the heads of the nuclear families. It must be borne in mind that the exhortation to the godly family which commenced in Ephesians 5:21

\footnotetext{
${ }^{4}$ Merriam Webster's Dictionary and Thesaurus in 2008 Ultimate Reference Suite

${ }^{5}$ Douglas Rhymes, 13
} 
was actually addressed to every member in the family. Children were called upon to obey their parents 'goneusin' in the Lord (Eph. 6:1). Further emphasis was laid on this in verse 2 as Paul explained what he meant by parents. These were the fathers and the mothers, but the headship of the home from creation was given to the man.

In another dimension, it is representational. The father remains the representative of the family. Several times in the Old Testament men were treated as representatives of their families. So in our text and in Colossians 3:21, Paul did not bother addressing 'goneusin'. In limited words, he simply addressed the 'pateres' as representatives of the parents. In essence, the usage of 'pateres' here could be metonymical.

\section{PARENTAL ROLES}

The duty of raising children up to a stage before the society begins to actively influence the child remains the primary role of the parents. The parents are given the charge not to provoke the children but to bring them up in nurture or nourishment and admonition of the Lord. The charge not to provoke to wrath should be seen in two phases.

Parents were not prevented from disciplining their children as some thought. Parents were rather cautioned against the brutality of child abuse. Craig Keener relayed to us that Paul was among the minority of ancient writers who opposed excessive discipline and brutality of children. ${ }^{6}$ This is because Greek and Roman society was harsher on newborn children. These children were not legally recognized until the parents accepted and introduced them into the society. Parents had the right to abandon or reject newborn babies, and if maimed or deformed parents could kill the children. It was only the Jewish community that opposed abortion and brutality to children.

However, against this backdrop Paul wrote to address the discipline of minors in the household. ${ }^{7}$ Paul used the words 'mee parorgizete' 'enrage not' to address the issue of brutality to children. The word as a present tense verb indicates that brutality to children was not a reported past event, for it was an act that was on going at the writing of the epistle, and even to the present age. 'Parorgizete' is a second person plural verb which means to 'enrage' or 'provoke to wrath' another person. It carries the idea of ill treatment being meted to someone who does not deserve it. How are children being enraged? Paul did not explain how children are provoked to wrath in his epistle but rather suggested ways not to provoke them. He commanded that children should be raised in the nurture and admonition of the Lord.

Parents are however, enjoined to bring up or raise 'ektrephete' their own children. 'Ektrepho' is an imperative which means 'to rear up to maturity, to cherish, to train, to bring up and to nourish'. In the LXX or Septuagint, ${ }^{8}$ same idea of 'bringing up' is conveyed in the following verses: Genesis 45:7, 11; 47:17; 2 Samuel 12:3; 1Kings 11:20. Sense of deliverance is also conveyed in the earlier listed verses. Paul was aware of the vulnerability of children and so sued for their deliverance and preservation.

This generation has witnessed uncountable assaults to children, among which are starvation, lack of medical attention, sexual molestation, kidnapping, ritual killings, maiming and other types of harry. Children are like young chicks waiting to be swallowed up by hawks of various kinds. It is the duty of parents to preserve their own children so that the claws of these hawks do not snatch them, deform them and render them incapable of functioning properly in the society. After all it was the action and or decision of the duo - the father and the mother, to bring a child into the world.

This idea of preservation put forth in Genesis 45:7, emphasizes on God the preserver, who sent Joseph ahead of the nation of Israel to preserve them from the approaching famine and all its aftermath. Life in the desert is susceptible to prevailing storms of surrounding enemies, hunger, thirst, loneliness and other uncertainties of life. But God was parenting Israel, defending and preserving them so that negative forces will

${ }^{6}$ Craig Keener, The IVP Bible Background Commentary: New Testament, (Downers Grove, Illinois: Intervarsity Press, 1993), 552.

${ }^{7}$ Craig Keener, 552

${ }^{8}$ Septuagint is the Greek version of Hebrew Bible. A Greek translation of the Hebrew Bible made in the 3rd and 2nd centuries BC to meet the needs of Greek-speaking Jews outside Palestine. It however contains some books not in the Hebrew canon 
not wipe them off the face of the earth. In the same vein, God committed to parents the duty of preserving and hiding their own children from the ills of the society.

'Ektrepho' also carries with it the sense of cherishing. A cherished person is one to whom affection is shown, a person that is thought of (or harboured) deeply and resolutely in one's mind; a person that is kept or cultivated with care and affection. This is the place children should occupy in the bosom of their parents: the lofty place of love, care and esteem.

So, provision of nourishment for the proper growth of the child is not negotiable. Nourishing and nurturing give the picture of a young plant that has just been transplanted and is being cared for in order to survive. The picture of the farmer in Isaiah 5 surfaces here. God the farmer did a lot in order to provide food for His vine plant on the ten-acre vineyard. He provided a very conducive atmosphere for the proper growth of His plants. He plowed the land; removed rocks, stones and thorns; applied fertilizers; provided water, staked the plants and kept pests away from the farm. Parent will do well to nourish their children well so that these children will not look outside for care that is not given inside the home.

However, the quest to meet the physical needs of children has overtaken the concern for other needs of the children. Children have psychological need as much as adults. Their need for affection is equally as important as their need for food. When parents assume that all the child needs is food, it becomes a problem when the child gets closer to the person that gives him/her needed affection. Parents need to remember that affection and esteem are in the package of cherishing a child. A child that is shown true love at home will be able to spot when a wrong affection is being presented outside.

But at some point children are seen and treated as unnecessary burden. Children are heritage from God and so are supposed to be the delight of every home and the society. But in some sphere they are seen and treated as parasites or unwanted intruders. The continuity of the society depends on the arrival of newborn in the community. God has created the home as the factory where children should be cherished and groomed for continuity of the society. Parents are charged not to give birth to number of children that they cannot cater for. This is because as long as the society is being populated by children, parents have the duty to nourish, cherish and preserve their children.

Another duty that Paul enumerated in Ephesians 6:4 is the duty of training. This is put forward by the word 'paideía.' Paideía conveys the message of tutorage, educating or training. Paideía relates to the upbringing of children, who need direction, teaching, instruction, and discipline. It indicates both the way of education as well as its goal. ${ }^{9}$ The goal of education as Paul told Timothy is to be godly and therefore selfdisciplined (1Timothy 4:7). "Paideia denotes the upbringing and handling of the child who is growing up to maturity and thus needs direction, teaching, instruction as well as certain measure of compulsion in the form of discipline or even chastisement. Paideia is both the way of education and cultivation which has to be traversed and also the goal which is to be attained." 10

Instruction - teaching should begin with thorough instruction in table manners, spiritual and moral values. It is the primary responsibility of parents to see that a child understands exactly what is expected of him/her in the society. Children should be shown the procedure of making friends, making home and maintaining neatness of the home and the body (Psalm 123:2). Connecting to Proverbs 22:6, parents are to train up a child not simply the way he/she should go, but also in the specific and unique way in which he/she should go.

Teaching involves establishment of certain rules. When there are no rules, firmly set and kept, a child's life is tossed about on the shifting tides of feelings and impulses. It could be the child's, the parent's or the peer's. Parents need to set different rules for different ages of the children. Children at all ages need direction and depend on their parents to establish order in their lives because they thrive on set order and routine.

Children should be taught about money and they should not be given more than they need for food and clothing. Too much money on them may latter result in extravagant, unsatisfied and compulsive spending. About making friends, parents must as a matter of necessity, know the friends of their children, and the parent of

\footnotetext{
9 Theological Dictionary of the New Testament, "Kittel," Biblesoft, DVD, (Cooks Communications Ministries, 2000).

${ }^{10}$ TDNT, BibleSoft, DVD, (Colorado: Cooks Communications Ministries, 2000) 
such friends so that both can join hands to train the children. If the other family's values clash with their own family, then the friendship needs to be reevaluated with their own children.

Exemplary living - parents remain the first and best example a child can depend on. Children often copy and build their own behavioural pattern on their parents'. The power of example in a parent does more to train a child than any other single thing. It is unreasonable to expect moral success with our children, without submitting ourselves to the laws of morality. Parents must themselves be the embodiment of their teaching, if they want their authority to be established.

Discipline - is training meant to ensure proper behaviour. It is the practice or methods of teaching and enforcing acceptable patterns of behavior. God gave this duty primarily to parents especially at the early stages of life of the child. God holds parents accountable for the discipline of their children. In Proverbs 22:15, parents are called upon to discipline their children and use the rod when necessary. The rod is an extrinsic factor that helps to build intrinsic discipline tendency and character in the child. A firm stand by a parent with one child (especially the older child) will usually have a salutary effect on the other children in the family, for it brings a spirit of authority into the house. Continued threat, angry exclamations followed by no acts are worthless and they produce indifference in children and cause their respect to their parents to decline.

This was the case with Eli the priest and his sons: Hophni and Phinehas. God punished them not only because of the wickedness of the children, but also as a result of the indifference of Eli (1Samuel 2; 3:13-14). A great lesson to learn from here is that when the sentence against an evil work is not executed speedily, the hearts of the sons of men settle fully to do evil (Eccl 8:11).

The fourth word, nouthesia has to do with guidance. It is a way of calling the attention of a child to an omission or what is required of him or her. It is hortatory in nature but could also be a subtle way of rebuke. Parents need to spend time, efforts and resources in teaching and instructing their children as regards good habits, normal path and moral behavior. As they do this they build neatness and thoroughness in the child. The child's attitude to work should be worked on, he/she should be taught the proper perspective as regards rest, leisure, relaxation time, school time, music time and sports time. This is because work prevents juvenile delinquencies and idle hand still remains the devil's workshop.

A major menace in the society is the unavailability of parents. The absentee parents have replaced their presence with television and videos including dishes and internet facilities. The gullible child feeds his/her minds on these fungi of ideologies unchecked by the parents. Through these media, the young ones are exposed to violence (the use of arms). It also exposes them to open sex. They watch erotic scenes and pornography at will and for as long as they want. When a boy and a girl stay together watching pornographic scene, they also had the liberty to practice what was taught them on the television. Through this medium a number of young boys and girls have been sexually abused by the people left to supervise them at home.

The media also exposes children to immodesty in dressing. As children watch celebrities dress on the Television and also observe what the parents put on their bodies in the name of clothes, children then form their own idea of what modesty in dressing is all about. So parents need to remember that to "surrender to the world of fashion, at the expense of modesty, betrays a spineless faith which knows nothing of the call to holiness" $"$.

Furthermore, truthfulness, faith and modesty are other cardinal virtues that youth need to imbibe. With guidance they are not difficult of attainment, and they are the foundation of all genuine character and prove of sincere Christianity. This must begin with the parents themselves and then imparted to the children. When these virtues have taken root in the child, a parent has the greatest consolation as he/she watches the child grow up and leaves the home.

Children sometimes deserve some hours of free actions and some self chosen pursuit. But this must be supervised and monitored. Parents must never abandon their God-given oversight. Parent must always keep in mind, that a child's desire for freedom runs ahead of his/her capacity for freedom. It is the parents' duty to determine the amount, kind and nature of freedom which his/her maturity can have and handle.

In ages gone by, chaperons were provided for youth at periods when they mature enough for dating. Chaperon is a person who for propriety accompanies one or more young unmarried women in public or in

${ }^{11}$ Larry Christenson, The Christian Family (Minneapolis, Minnesota: Bethany Fellowship1970), 77 
mixed company. The purpose of the chaperon is to ensure proper behavior, so that shame is not brought on the family. Today youth like to do a lot of things under cover, they do not want the older folks to see what they are doing. They protest when older folks demand explanation. In the days when chaperons' services were employed, confusion was less witnessed amongst boys and girls.

\section{WAY FORWARD}

In view of the foregoing, there has to be ways forward if the society wants to buy back some of the earlier enumerated virtues. Here are some suggestions:

Empowering Parents should be a priority of the government. If parents don't work, it will be impossible for them to meet the needs of their children, thereby abandoning the children to fend for themselves, which breeds vagabondism, street begging and lack of respect for their parent. It is clear that any youth who does not respect his/her parents will find it hard to respect anyone outside.

The Church primarily and other religious bodies have a huge obligation to promote family values. This should be done through teachings in gatherings and creating monitoring facilities which monitors the effectiveness of the teachings of the clergy. The need to relate with members outside the walls of the congregating halls is highly necessary now that the life members live outside, i.e. at homes and at work negate the godly messages they congregate to hear every Sunday.

Parents may need to get people at the vicinity where their children reside to carry out the duties of chaperons and ensure the safety of their children in relationship.

\section{CONCLUSION}

We began by examining the situations under which families operate in today's society. These situations have shaped the society and have created the scene witnessed in every sphere. But then we took some time to expose Paul's recommendations for the family. It is then clear that the abdication of parental responsibilities have been at the plinth of society ills. The way forward is for the parents to face realities, heed the word of God and take up the responsibility of nurturing, guiding and protecting their own children.

\section{Books}

[1] Rhymes, Douglas, Prayer in the Secular City (Pennsylvania: Westminster Press, 1967) (4).

[2] Keener, Craig, The IVP Bible Background Commentary: New Testament (Downers Grove, Illinois: Intervarsity Press, 1993). (2)

[3] Christenson, Larry, The Christian Family (Minneapolis, Minnesota: Bethany Fellowship, 1970) (1)

\section{Computer Software/DVD}

[4] Merriam Webster's Dictionary and Thesaurus in Ultimate Reference Suite, Encyclopaedia Britannica 2008 (1)

[5] Theological Dictionary of the New Testament, "Kittel," Biblesoft, DVD, Cooks Communications Ministries, 2000 (2) 